\author{
Distribution Category: UC \\ Key Words \\ Burial Ground \\ Waste \\ Transuranic \\ Vegetation \\ Transport
}

\title{
Vegetation Uptake from Burial Ground Alpha Waste Trenches
}

C.E. Murphy Jr. and R.C. Tuckfield

Approved by:

D. B. Moore, Research Manager

Environmental Science Section

Savannah River Laboratory

Publication Date:

\section{DISCLAIMER}

This report was prepared as an account of work sponsored by an agency of the United States Government. Neither the United States Government nor any agency thereof, nor any of their employees, makes any wartanty, express or implied, or assumes any legal liability or respotsibility for the accuracy, completeness, or usefulness of any information, apparatus, product, or process disclosed, or represents that its use would not infringe privately owned rights. Reference herein to any specific commercial product, process, or service by trade name, trademark, manufacturer, or otherwise does not necessarily constitute or imply its endorsement, recommendation, or favoring by the United States Governmel' or any agency thetzof. The views and opinions of auchors expressed herein do not necessarily state or reflect those of the United States Government or any agency theresf.

\section{Westinghouse Savannah River Company Sanannah River Site Aiken, SC 19808}

PREPARED FOR THE U.S. DEPARTMENT OF ENERGY UNDER CONTRACT DE-AC09 88SR18035 


\section{DISCLAIMER}

This report was prepared as an account of work sponsoied by an agency of the United States Government. Neither the United States Government nor any agency thereof, nor any of their employees, makes any warranty, express or implied, or assumes any legal liability or responsibility for the accuracy, completeness, or usefulness of any information, apparatus, product, or process disclosed, or represents that its use would not infringe privately owned rights. Reference herein to any specific commercial product, process, or service by trade name, trademark, manufacturer, or otherwise does not necessarily constitute or imply its endorsement, recommendation, or favoring by the United States Government or any agency thereof. The views and opinions of authors expressed herein do not necessarily state or reflect those of the United States Government or any agency thereof.

This report has been reproduced directly from the best available copy.

Available to DOE and DOE contractors from the Office of Scientific and Technical Information, P.O. Box 62, Oak Ridge. TN 37831; prices available from (615) 576-8401, FTS 626-8401.

Available to the public from the National Techncial Information Service, U.S. Department of Commerce, 5285 Port Royal Rd., Springfield, VA 22161. 


\section{ABSTACT}

This study was conducted as part of an evaluation of the potential radiological consequences of reinhabiting the SRS burial ground. The objectivu was to determine the uptake of buried, low-level, transuranic waste from unlined earthen trenches by forest vegetation. Two tree plots were established in 1979. One plot w/as put over a trench containing alpha waste and the other in an area without trenches. When the tree seedlings were sampled during 1979 and 1980 , and analysized for ${ }^{239} \mathrm{Pu}$ and ${ }^{238} \mathrm{Pu}$, there was only a small difference in radionuclude concentration between trees planted over the trench anc those planted on the control plot because of the limited root intrusion into the trench by the seedlings. However, when trees were sampled in 1986, 1987, and 1988 and analyzed for ${ }^{241} \mathrm{Am},{ }^{238} \mathrm{Pu},{ }^{239} \mathrm{Pu}$, and ${ }^{237} \mathrm{~Np}$ activity, the average activity of all of these isotopes $\mathrm{w}$ as significantly higher over the trenches than in the control plot.

These measurements indicate that tree roots will extract transuranic isotopes from buried, low-level waste. The amount of radioisotopes moved from the trenches to the surface is small and the level in the trees is low enough that dose from exposure will be small. The long term effects of transport of radioisotopes from the trenches to the surface soil was evaluated by estimating the accumulation in the surface soil. Transuranic activity in selected food crops was calculated using the soil activity and the literature derived concentration factors. In all cases, the activity of the transuranic isotopes in the edible portion of the plants was quite low. The activity in the leaf tissue was much higher than in the seed. However, it should be noted that in only one case was the activity higher than the naturally occurring activity of ${ }^{40} \mathrm{~K}$ in the pine foliage. 


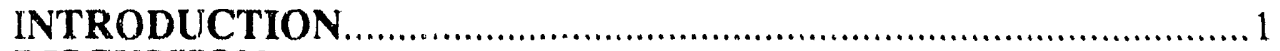

DISCUSSION

RESULTS.

Graphical and Descriptive Analysis..............................................3

Statistical Analysis...................................................................... 3

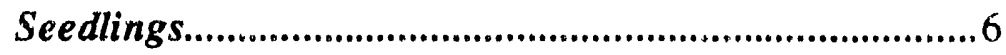

Repeated Measures Analysis........................................7 7

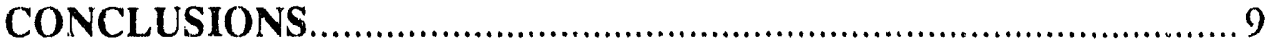

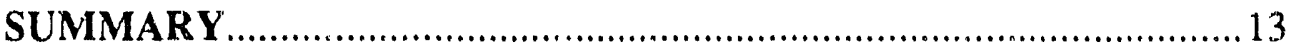

REFERENCES

APPENDIX 
1 The number of hits of activity and the soil activity encountered by soil coring of the burial trench.

2 The average activity in tree leaves on the control and trench plots for all of the measured radionuclides. .4

3 The average difference between trench and control plot radionuclide activity for each transuranic nuclide measured for the year measured.

4 The average ${ }^{238} \mathrm{Pu}$ activity difference between tree $\mathrm{I}$ aves collected in 1979 and1980 in trench and control plots for each tree species

5 The average ${ }^{239} \mathrm{Pu}$ activity difference between tree leaves collected in 1979 and1980 in trench and control plots for each tree species. .8

6 A comparison of the average radionuclide activity of pine needles in control and trench plot trees for each year of sample collection. 
1 Geometric means of plutonium isotope concentration of seedlings from trench and control plots containing three species during the two year period (1979-1980).

2 Summary of treatment (plot, year, and species) effect for tree seedlings (1979.1980)

3 Summary of treatment (plot and year) effect for ${ }^{238} \mathrm{Pu}$ and ${ }^{239} \mathrm{Pu}$ using the data for all years $(1979,1980,1986.1988)$

4 Geometric mean concentration of seven radionuclides from trench and control plots during the three year period(1986-1988)

5 Summary of treatment (plot and year) effect significance from a Repeated Measures ANOVA of the log-transformed concentrations of seven radionuclides.

6 Average transuranic isotope activity, estimated isotope transport, and projected 100 year soil accumulation activities over burial trenches.

7 Concentration ratios of transuranic isotopes for selected food plants.

8 Projected transuranic isotope activity in food grown in soil after 100 years of vegetation transport from the burial trench to the soil surface 15 


\section{VEGETATION UPTAKE FROM BURIAL GROUND ALPHA WASTE TRENCHES}

\section{INTRODUCTION}

The conseçuences of the returning the Savannah River Site (SRS) burial ground area to general nublic access at the time of completion of the SRS mission is being investigated. As part of the program, the uptake of radionuclides by vegetation planted over the burial ground alpha trenches is being studied. This study includes evaluation of the radiological impact to inhabitants of the area under a number of scenarios that include the return of the land to farming or forestry use with or without exhumation of the buried waste.

In the hot, humid climate of the SRS area it is inevitable that the burial ground will return to forest vegetation if the site is completely abandoned. While this would have the desirable effect of limiting erosion, it can be expected that the tree ronts will penetrate the low-level buried waste trenches and provide a vector for movement of radionuclides to the surface. While there have been a number of studies of agricultural species grown on contaminated soil, at SRP and other sites ${ }^{1}$, there are few studies involving forest vegetation. This study was established with the objective of determining the uptake of buried, low-level, transuranic waste from unlined earthen trenches by forest vegetation.

\section{DISCUSSION}

From SRS startup to 1966 , solid waste contaminated with alpha-emitting transuranic nuclides was buried, unencapsulated, in earthen trenches. From 1966 to 1974, higher concentrations of alpha waste were encapsulated, but alpha waste with $<0.1 \mathrm{Ci} /$ package continued to be buried unencapsulated. Since 1974, all alpha waste $>10 \mathrm{nCi} / \mathrm{g}$ have been stored retrievably. Plant records show that about $4000 \mathrm{Ci}$ are associated with unencapsulated alpha waste. This includes about 2600 Curies of plutonium-238 $\left.{ }^{238} \mathrm{Pu}\right)$ and 500 Curies of plutonium isotopes 239 and 240 (referred to as ${ }^{239} \mathrm{Pu}$ in the body of this report) buried in about 4 million cubic feet of trench. Other transuranic nuclides known to be in trench waste include curium-244 $\left({ }^{244} \mathrm{Cm}\right)$, americium-241 $\left({ }^{241} \mathrm{Am}\right)$, and neptunium-237 $\left({ }^{237} \mathrm{~Np}\right)$.

The burial trenches were nominally 20 feet deep and were capped with 4 feet of clean soil. This left the base of the trenches about $20 \mathrm{ft}$. above the water table which averages about 40 foot in depth in this area ${ }^{2}$. The trench picked for this study was filled in the early period of plant operation, around 1953. The results of an intensive study of this trench was reported by Johnson and Wilhite ${ }^{3}$.

Two tree plots were established, one over a trench in the original burial ground and the other in an area without trenches in the "new" burial ground between buildings 643-G and 643-7G. Each plot is 32 feet wide by 112 feet long. The upper six irches of soil was removed from both sites to minimize contamination due to atmospheric fallout from the F-and $\mathrm{H}$-Area stacks. The soil on the plets was tested and then limed and fertilized according to local agricultural practices. Then the upper twelve inches of soil was mixed with a harrow. Prior to establishment of the sites, the area was mulched with straw to retain moisture, reduce dust, and discourage weeds.

Three species of trees were planted: loblolly pine (Pinus taeda L.), sweetgum (Liquidambar styraciflua L.), and willow oak (Quercus phellos L.). All are native species. 'The 
pine is one of the most vigorous pioneer tree species growing in this area. The willow oak and sweetgum are usually more numerous in wetter sites than found in the burial grov:..i out both could be occasional species even in this type of site. Each plot was divided into four subplots. T'wo of the subplots were planted with pine trees, and one of the remaining plots was planted in oak and the other plot was plant in sweetgum. The trees were planted in three rows, six feet apart. A total of 18 sweetgum, 15 oak, and 36 pines were planted on each plot. The center row of the planting was placed along the centerline of the trench. The pine seedlings grew much more vigorously and had a higher survival than the other species. For this reason, sampling of the two hardwood species was discontinued after 1980 .

In the two years following establishment of the tree plots, 1979 and 1980 , whole trees of each species were collected from each plot for ${ }^{239} \mathrm{Pu}$ and ${ }^{238} \mathrm{Pu}$ analysis. In some cases, the trees were divided into leaf, branch, and stem. In other cases, the whole tree was analyzed. The trees were analyzed by the SRS Environmental Measurements Group. In 1979, soil samples were taken adjacent to each tree sampled. In addition, soil data was available from cores taken in 1979 to characterize the transuranic content of the trench. The vegetation samples were ashed. Plutonium concentration in the vegetation ash and dry soil samples were counted by alpha spectrometry.

The results of sampling of the alpha waste trenches has been presented by Johnson and Wilhite ${ }^{3 .}$ Some of their results will be included in this report in order to characterize the trench where this study was done. The sampling was done with 2 inch diameter split-tube and 3 inch diameter Shelby samplers. The Shelby samplers proved to be the most reliable in terms of returning a soil core and account for most of the data. The cores were sampled in two foot intervals from the surface to 22 feet. In their report, the cores were tabulated by two foot depth intervals in terms of average number of strikes of buried waste materials, the percent of tubes retaining whole soil cores, and the activity of soil. Cores which struck buried material rarely retained a full soil core. Nineteen cores containing 159 segments from 100 linear feet of trench length were: take in the vicinity of the location later used for the vegetation uptake study.

Beginning in 1986, needle samples have been collected from selected pine trees in each of the plots. Because of poor growth and survival, the hardwood trees were not sampled. In 1986, thirty-one trees remained on the plot over the alpha trench and 26 trees remained on the control plot. During the three years of the study, there has been an increase in the mortality of the trees in the control plot. This appears to have been caused by an increase in the use of herbicides on the steam-line right-of-way adjacent to the plot. In 1988, only 20 trees remained. The alpha trench trees are further away from the right-of-way and do not appear to have been harmed.

Needles were sampled from five trees in each plot during September of 1986 and August of 1987, and 1988. Approximately 500 grams, fresh weight, of needles were removed from each tree. The needles were taken from the base of the branches and represented needles which started growth two springs before sarnpling (loblolly pine has two years of needles on a branch through the summer of each year dropping to one age class of needles during the fall and winter).

The needles were stored frozen until shipment for analysis by an offsite vendor. The first two years of analysis were by TMA-Norcal of Richmond, Cal. The 1988 samples were done by TMA-Eberline of Albuquerque, NM. The samples were analyzed for gamma 
emitting nuclides with a GeLi detector and ${ }^{239} \mathrm{Pu},{ }^{238} \mathrm{Pu}$, and ${ }^{241} \mathrm{Am}$ by alpha spectrometry. In $1987,{ }^{237} \mathrm{~Np}$ was added to the list of radionuclides.

As described previously, the radionuclide analyses are from three different sources, using slightly different analysis procedures, and were reported in different units. The $\mathrm{Pu}$ analyses done by the SRS Environmental Measurements Group were reported as $\mathrm{pCi} / \mathrm{gm}$ of ashed tissue. The analyses done by TMA-Norcal were reported in pCi/gm dry weight. The analyses done by TMA-Eberline were report $\mathrm{d}$ in $\mathrm{pCi} / \mathrm{gm}$ wet weight. Conversion from ash weight to a dry weight basis was done under the assumption that the fraction of ash to dry weight was $0.03^{4}$. Conversion from wet weight to a dry weight basis was done on the assumption of a v'ater content (wet weight less dry weight divided by dry weight times 100) of $150 \%{ }^{4}$. A con parison of the ${ }^{40} \mathrm{~K}$ activity after conversion from wet weight basis to dry weight basis confirmed the value of water content used.

\section{RESULTS}

\section{Graphical and Descriptive Analysis}

Figure 1 illustrates some of the results of coring the waste trenches. The activity in the soil does not include all of the activity available to tree roots. Some of the buried waste had higher activity than the soil around it. The highest activity encountered in the waste was around 100,000 counts/minute as measured with a portable alpha counter. While these measurements were not converted to an activity to weight basis, this waste is the source of the highest soil activity of approximately $400 \mathrm{pCi} / \mathrm{gm}$ and is almost certainly higher in specific activity than the soil around the waste.

Depth, ft.

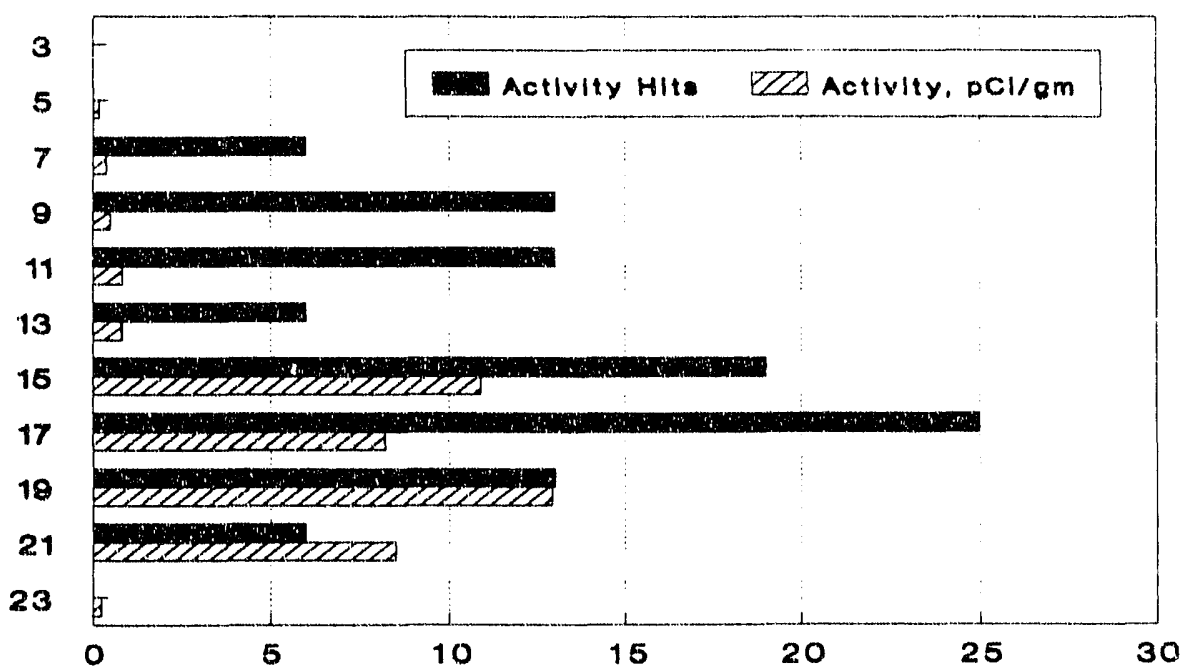

Figure 1.The Number of Hits of Activity and the Average Soil Activity Encountered by Soil Coring of the Burial Trench. 
The soil activity shows a general trend of increase from the surface to about $10 \mathrm{ft}$. after which there is an abrupt increase in activity which then remains relatively constant to near the bottom of the trench, at $20 \mathrm{ft}$. The activity immediately beneath the trench is only slightly higher than the activity above the trench indicating that vertical migration through the soil below the trench has taken place at a slow rate. The number of strikes of waste objects is in general agreement with the level of activity measured. Many of the strikes were either paper or wood. In most cases, neither of these types of material had degraded very much since they were buried at least twenty-five years earlier.

Preliminary analysis of the data was done by plotting averages of the individual radionuclide activities for control and trench plots (Figure 2). This plot indicates that there is a an apparent increase in the activity of the needles for the four radionuclides known to be in the trench waste. The three other radionuclides shown in figure 2 are greater than the minimum detection level of the analysis. Potassium $-40\left({ }^{40} \mathrm{~K}\right)$ is a naturally occurring radionuclide. Zinc-65 $\left({ }^{65} \mathrm{Zn}\right)$ and cesium-137 $\left({ }^{137} \mathrm{Cs}\right)$ are part of the environment from nuclear activities but were not expected to be elevated above environmental levels in this waste material. The average levels of ${ }^{137} \mathrm{Cs}$ and ${ }^{40} \mathrm{~K}$ are higher in the control plot than in the trench plot, 'uggesting that the activity of these radionuclides is not related to the waste in the trench.

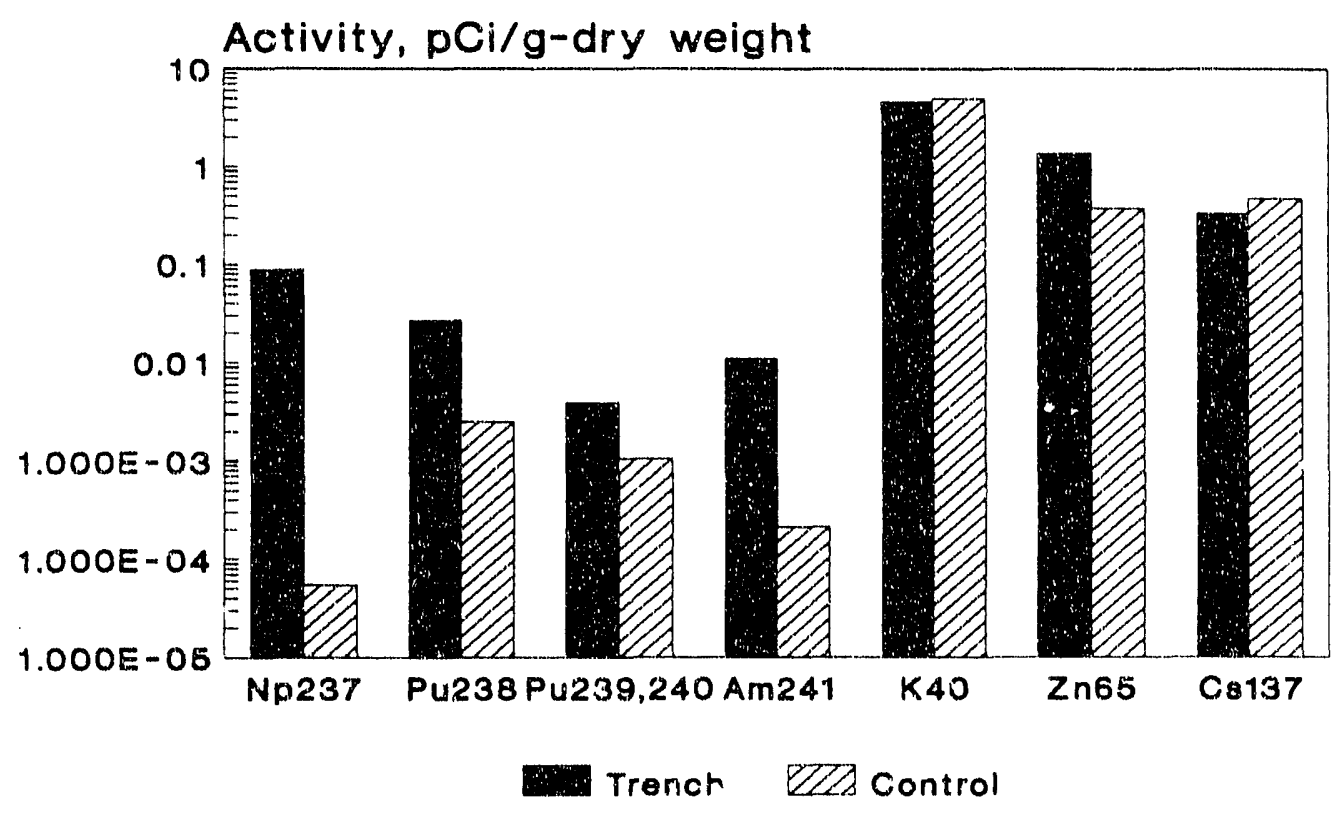

Figure 2. The Average Activity in Tree Leaves on the Control and Trench Plots for All of the Measured Radionuclides. 


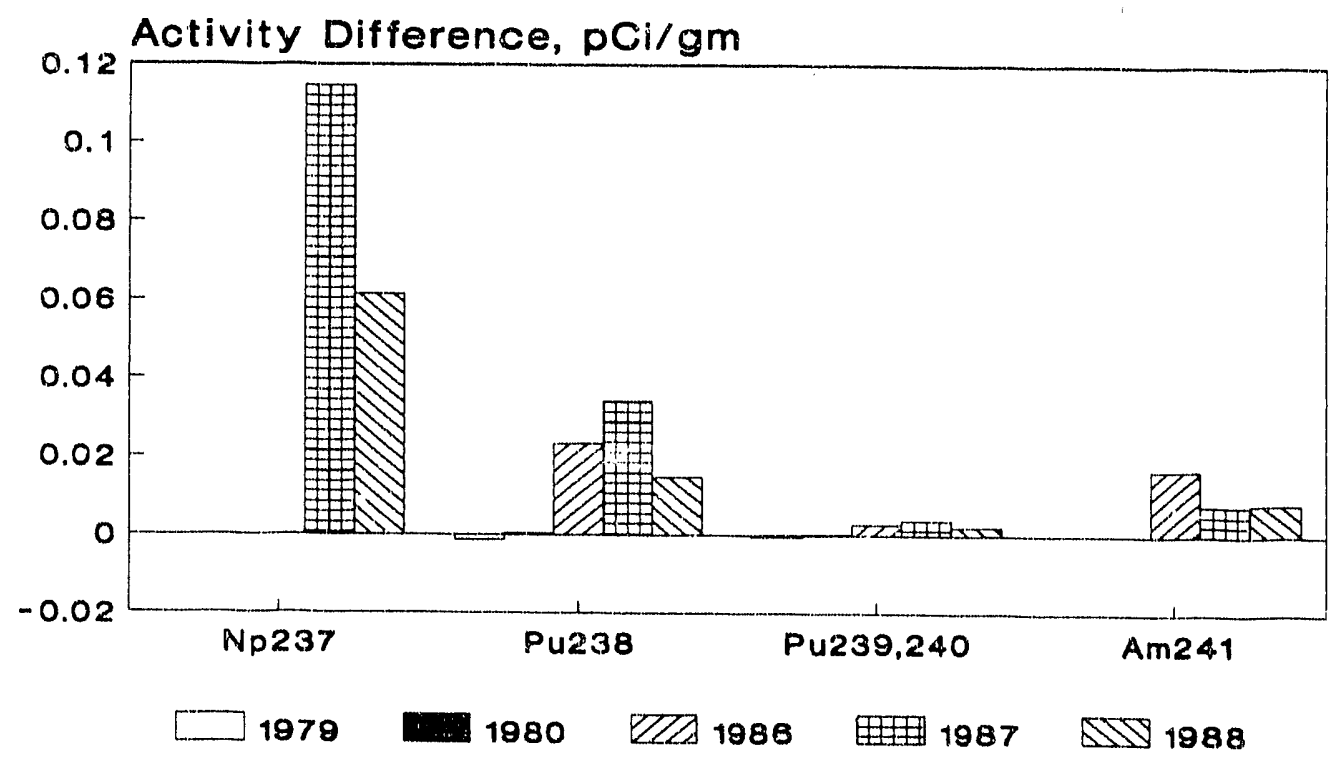

Figure 3. The Average Difference between Trench and Control Plot Radionuclide Activity for Each Transuranic Nuclide Measured for Each Year Measured.

The source of the ${ }^{65} \mathrm{Zn}$ is unknown. With a 245 day half-life, it is extremely doubtful that the levels could have been high enough in the original waste to be present now. However, zinc is actively taken up by plants as a micronutrient ${ }^{5}$ and would have a much higher uptake than the transuranic nuclides for any given level of activity in the trench.

The difference between the trench and control plot for each year of the study for each radionuclide is illustrated in Figure 3. There is no apparent time trend in the difference between plots during the period from 1986 through 1988. However, it appears that the difference in the plutonium isotopes between the control and trench plots was very small when the trees were seedlings in 1979 and 1980.

The results of the plots suggest that there were some consistent differences in the average activity of some of the radionuclides. However, even 'hough the samples with the highest activities of the radionuclides measured were from the trench plot, some samples from the trench plot were lower in activity than some of the samples from the control plot. For this reason, it was decided to statistically analyze the data tu provide a systematic method of determining the probability that the differences observed between trench and control plots were caused by the presence of the trench materials and not by random variability in the radionuclide content in the natural en:'ironment. 
The statistical tests were designed to answer three questions 1 ) was there an effect of tree species, year of collection, or plot (control or trench) on the activity of any of the radionuclides measured in the seedling trees, 2 ) was there any difference between the activity of any of the radionuclides measured in the pine trees when they were seedlings and after they had grown, and 3) was there an effect of year of sampling or plot on the activity of any of the measured radionuclides in the grown pine trees.

\section{Statistical Analysis}

Environmental contaminants such as radionuclides typically show skewed data distributions with relatively many small concentration values and relatively few large concentration values. Asymmetric distributions often preclude the assumption that the underlying population of concentration values is normally distributed.

In such instances, the normal probability model is often replaced by the log-normal probability model. This means that the logarithms of the contaminant concentrations are assumed to be normaily distributed ${ }^{6}$. All statistical tests are performed, therefore, on the logtransformed data.

The small sample sizes in the present study were not sufficient to test the normal or lognormal assumptions. Instead, both the natural log-transformed and untransformed (original scale) data were used for statistical analysis. If there was little difference in the results the untransformed results are reported. Otherwise, the log-transformed results are reported.

When log-transformed measurements were used, average concentrations for the corresponding statistical analyses are reported as geometric means. The geometric mean is the mean of the logarithms back-transformed (i.e. exponentiated) to the original scale.

One additional consequence of using log-transformed data has to do with the statistical hypotheses being tested. On the original, untransformed scale, we are interested. in a test of the hypothesis that there is no difference in the arithmetic mean radionuclide concentrations between plots or years. On the log scale, this is equivalent to a test that the ratio of the respective geometric means is equal to one.

All data, including the data collected when the trees were seedlings, were analyzed by an analysis of variance procedure (ANOVA). For the seedling ANOVA, the main effects include treated versus control plots, the seedling species, and the year of data collection. Then the analysis of variance procedure was used to determine the effect of tree age (seedling versus grown) on radionuclide activity levels for the two plutonium isotopes measured during both periods.

A Repeated Measures ANOVA $^{7}$ was chosen for the statistical analysis of the radionuclide concentrations in the pine needles of grown pine trees. The effects tested included treated versus control plots, growth year, and the interaction of plot and year. This method was preferred because radionuclide concentration measurements were repeatedly made on the same experimental units (i.e. trees) at successive time periods, in contrast to the seedling measurements in which it was necessary to sample the whole tree. 
All analyses were performed using the SAS statistical computing software ${ }^{8}$. PROC GLM, with the REPEATED statement for the 1986 through 1988 period, produced appropriate tests of each main effect and interaction and resulted in a significance probability or $p$-value. The p-value is the probability of a false positive conclusion, that is, of conduding that there is a significant effect due to plot or year when, in fact, there is not.

Appendix A contains a listing of the conrentration measurements for each individual sample and radionuclide. Note that measurements for ${ }^{237} \mathrm{~N} \mathrm{~Np}$ for 1986 were unavailable and $0.21{ }^{239} \mathrm{Pu}$ and ${ }^{238} \mathrm{Pu}$ activities were measured in the tree seedlings sampled in 1979 and 1980.

\section{Seedling Analysis}

The geometric means and $1 \mathrm{~g}$.transformed ANOVA results are given in Table 1 and 2 , respectively. There is no signiticant effect of year of data collection or treatment for either ${ }^{239} \mathrm{Pu}$ or ${ }^{238} \mathrm{Pu}$. However, there is a significant effect of species for ${ }^{238} \mathrm{Pu}(\mathrm{p}<.001)$, but not for ${ }^{239} \mathrm{Pu}(\mathrm{p}<.64)$. The results are illustrated in Figures 4 and 5 which show the difference in mean activity for the samples between years for each species by treatment. It is clear that the effect of species noted above is for pine trees alone, and is greater in one year than the other. While the activity levels are low cornpared to later samples taken on grown pine trees, it is possible that the faster growing pines have penetrated the waste during the second year.

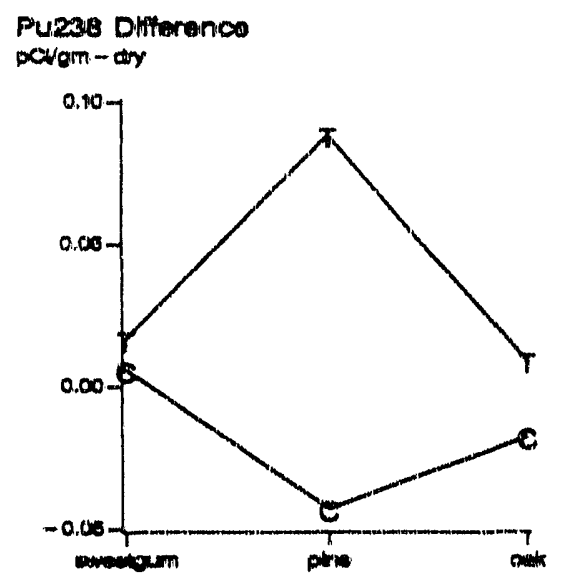

Figure 4. The average $2010 \mathrm{~F}$ activity difference between tree leaves collected in 1979 and 1980 in trench and control plots for each tree species.

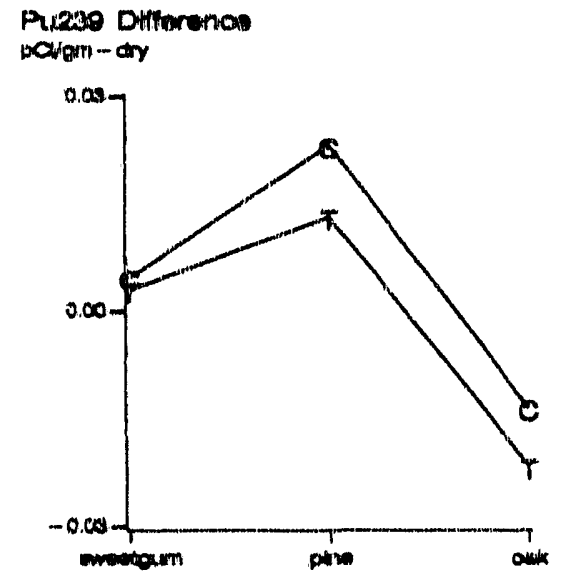

Figure 5. The Average ${ }^{239} \mathrm{Pu}$ activity difference between tree leaves collected in 1979 and1980 in trench and control plots for each tree spe. cies. 
Table 1. Geometric Means (pCi/gm-dry) of Plusonium Isotope Concentration in Seedlings from Trench and Control Plots for Three Species during the Two Year Period (1979.1980).

By Year

$\begin{array}{lll}\text { Year } & { }^{238} \mathrm{Pu} & { }^{234} \mathrm{Pu} \\ 1979 & .000826 & .000594 \\ 1980 & .000797 & .000706\end{array}$

By Plot and Year
By Species

$\begin{array}{lll}\text { Species } & { }^{238} \mathbf{P u} & { }^{239} \mathrm{Pu} \\ \text { oak } & .00102 & .000753 \\ \text { pine } & .00133 & .000770 \\ \text { sweetgum } & .000394 & .000511\end{array}$

By Species, Plot, and Year

\begin{tabular}{|c|c|c|c|c|}
\hline Species & Plot & Year. & ${ }^{2 x} \mathbf{P u}$ & ${ }^{239} \mathrm{Pu}$ \\
\hline oak & C & 1979 & .00154 & $m 123$ \\
\hline oak & C & 1980 & .000923 & .000582 \\
\hline oak & $\mathrm{T}$ & 1979 & .00158 & .000636 \\
\hline jak & $\mathrm{T}$ & 1980 & .000795 & .000813 \\
\hline pine & C & 1979 & .000719 & .000936 \\
\hline pine & $\mathrm{C}$ & 1980 & .00142 & .00127 \\
\hline pine & $\mathrm{T}$ & 1979 & .000891 & .000446 \\
\hline pine & $\mathrm{T}$ & 1980 & .00210 & .000631 \\
\hline sweetgum & $\mathrm{C}$ & 1979 & .000641 & .000571 \\
\hline sweetgum & $C$ & 1980 & .000371 & .000373 \\
\hline & $\mathrm{T}$ & 1979 & .000319 & .000235 \\
\hline veetgum & $T^{\prime}$ & 1980 & .000366 & .000808 \\
\hline
\end{tabular}

Table 2. Summary of Treatment (Plot, Year and Species) Effect for Tree Seedlings $(1979.80)$.

$\begin{array}{llcl}\text { Radionuclide } & \text { Plot } & \text { Effect Significance(p-value) } & \text { Soeciss } \\ { }^{238} \mathrm{Pu} & \text { Year } & \\ { }^{219} \mathrm{Pu} & -(.95) & -(.93) & \text { Strong }(.0001)\end{array}$


An analysis of variance was performed on the original and log-transformed plutonium isotope data to determine the effect of seedling versus grown pine trees on the activity in the needles. The ANOVA results (untransformed) show that there is a significant $(p<.0001)$ difference in the activity among years (Figure 2 ) when the two time periods are analyzed together for both radionuclides. These results are contained in Table 3. The expested effect of treatment (plots) is also significant $(\mathrm{p}<.0006)$. This confirms that radionivide uptake was higher in the grown trees than in the seedlings. This is consistent with minimum root penetration into the trenches by the pine seedlings.

Table 3. Summary of Treatment (Plot and Year) Effect for ${ }^{238}$ Pu aud ${ }^{239} \mathrm{Pu}$ Using the Data for All Years (1979,1980,1986-88).

Radionuclide

Blet

${ }^{238} \mathrm{Pu}$

${ }^{239} \mathrm{Pu}$
Strong $(.0006)$

Strong $(.0006)$

\section{Effect Significance (n-value)}

Year

Strong (.0001)

Strong $(.0001)$

Table 4. Geometric Mizan Concentration (pCi/gm-dry) of Seven Radionuclides from Trench and Control Plots during the Three Year Period (1986-1988).

Each Year (Averaged Across Plot Type)

$\begin{array}{llllllll}\text { Xear } & { }^{241} \mathrm{Am} & { }^{137} \mathrm{Cs} & { }^{40} \mathrm{~K} & { }^{237} \mathrm{Ng} & { }^{238} \mathrm{Pu}_{\mathbf{u}} & { }^{239} \mathrm{Pu} & { }^{65} \mathrm{Zn}_{\mathbf{n}} \\ 1986 & .000779 & 0.428 & 4.81 & & .00604 & .00223 & 0.571 \\ 1987 & .000728 & 0.364 & 4.18 & .00137 & .00988 & .00229 & 1.002 \\ 1988 & .000151 & 0.151 & 5.14 & .000294 & .00393 & .0000882 & 0.353\end{array}$

Each Plot Type (Averaged Across Years)

$\begin{array}{llllllll}\text { Year } & { }^{241} \mathrm{Am} & { }^{137} \mathrm{Cs} & { }^{40} \mathrm{~K} & { }^{237} \mathrm{Nn} & { }^{234} \mathrm{Pu} & { }^{239} \mathrm{Pu} & { }^{65} \mathrm{Zn} \\ \mathrm{C} & .0000703 & 0.346 & 5.13 & 0.000023 & 0.00166 & .000238 & 0.307 \\ \mathrm{~T} & .00237 & 0.236 & 4.35 & 0.0116 & 0.0204 & .00212 & 1.04\end{array}$

Each Combination of Year and Plot Type

\begin{tabular}{|c|c|c|c|c|c|c|c|}
\hline Year Plot & ${ }^{21} \mathrm{Am}$ & ${ }^{137} \mathrm{Cs}$ & ${ }^{n} \mathrm{~K}$ & ${ }^{237} \mathrm{NL}$ & ${ }^{238} \mathrm{Bu}$ & ${ }^{239} \mathrm{Pu}$ & \\
\hline $1986 \mathrm{C}$ & .000282 & 0.716 & 5.41 & & 0.00217 & .00162 & 0.31 \\
\hline $1986 \mathrm{~T}$ & .00215 & 0.255 & 4.27 & & 0.0168 & .00308 & 1.04 \\
\hline $1987 \mathrm{C}$ & .000141 & 0.440 & 4.28 & 0.000053 & 0.00241 & .00115 & $0.3 ?$ \\
\hline $1987 \mathrm{~T}$ & .00270 & 0.313 & 4.10 & 0.018530 & 0.0306 & .00397 & 2.43 \\
\hline $1988 \mathrm{C}$ & .00001 & 0.138 & 5.64 & 0.000012 & 0.000935 & .00001 & 0.28 \\
\hline $1988 \mathrm{~T}$ & .00227 & 0.165 & 4.69 & 0.007214 & 0.0165 & .000778 & 0.43 \\
\hline
\end{tabular}




\section{Repeated Measures Analysis}

For the grown pine trees, the results of the statistical analyses on the original scale were largely uninformative and generally showed no significant differences in radionuclide concentrations (except for ${ }^{238} \mathrm{Pu}$ and ${ }^{65} \mathrm{Zn}$ ) between plots or years. However, the same analyses for the log-transformed data did show significant patterns of radionuclide uptake. This was taken as evidence that the lognormal probability model was more appropriate than the normal probability model. Therefore, only the log-transformed analysis results are reported here.

Table 4 contains the geometric mean concentrations for each plot type (averaged across years), for year (averaged across plot type) and for each combination of plot and year. All radionuclides are represented in this table. For most radionuclides (excepting ${ }^{137} \mathrm{Cs}$ and ${ }^{40} \mathrm{~K}$ ), the geometric mean concentrations are an order of magnitude larger in the treated plots than in the control plots. It is also apparent from this table that ${ }^{137} \mathrm{Cs}$ was the only contaminant that showed consistent increase in geometric mean concentrations from 1986-1988.

Table 5 is a summary of the statistical test results from the repeated measures ANOVA. There was moderate or strong ( $p<.05$ or $p<.01$, respectively) eviderice to conclude that radionuclide concentration was higher in the treated plot pine trees than in control plot pine trees. The exceptions to this statement were ${ }^{137} \mathrm{Cs}$ and ${ }^{40} \mathrm{~K}$. For these contaminants, the

Table 5. Summary of Treatment (Plot and Year) Effect Significance from a Re* peated Measures ANOVA of the Log-transformed Concentrations of Seven Radionuclides .

\begin{tabular}{|c|c|c|c|c|c|}
\hline \multirow{3}{*}{$\begin{array}{l}\text { Radienuclide } \\
{ }^{241} \mathrm{Am}\end{array}$} & \multirow{3}{*}{$\frac{\text { Plot }^{\mathrm{a}}}{\text { Strong }}$} & \multicolumn{3}{|c|}{ Effect Significance } & \multirow[b]{2}{*}{ Interaction $^{c}$} \\
\hline & & & Year $^{6}$ & & \\
\hline & & $(.01)^{\mathrm{d}}$ & Weak & $(.06)$ & Weak (.06) \\
\hline${ }^{137} \mathrm{Cs}$ & 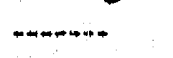 & $(.37)$ & Moderate & $(.04)$ & Weak (.08) \\
\hline${ }^{40} \mathrm{~K}$ & $\ldots$ & (.31) & $\cdots$ & $(.52)$ & $\ldots \quad(.90)$ \\
\hline${ }^{237} \mathrm{~Np}$ & Strong & $(.007)$ & Weak & $(.08)$ & $\ldots(.68)$ \\
\hline${ }^{238} \mathrm{Pu}$ & Strong & $(.001)$ & -...... & $(.33)$ & $\ldots \quad(.67)$ \\
\hline${ }^{9} \mathrm{Pu}$ & Moderate & $(.02)$ & Strong & $(<.001)$ & Strong (.009) \\
\hline${ }^{65} \mathrm{Zn}$ & Moderate & $(.04)$ & Strong & $(.01)$ & $(.28)$ \\
\hline
\end{tabular}

a) The effect due to the presence of radionuclides in the waste trench on the radionuclide concentrations in pine tree needles.

b) The effect of continued year-to-year exposure to radionuclides.

c) Interaction of effect measures whether the plot effect is constant from year-to-year

d) Significance probability (p-value) in parentheses. 
Figure 6. A comparison of the average radionuclide activity of pine needles in control and trench plot trees for each year of sample collection.

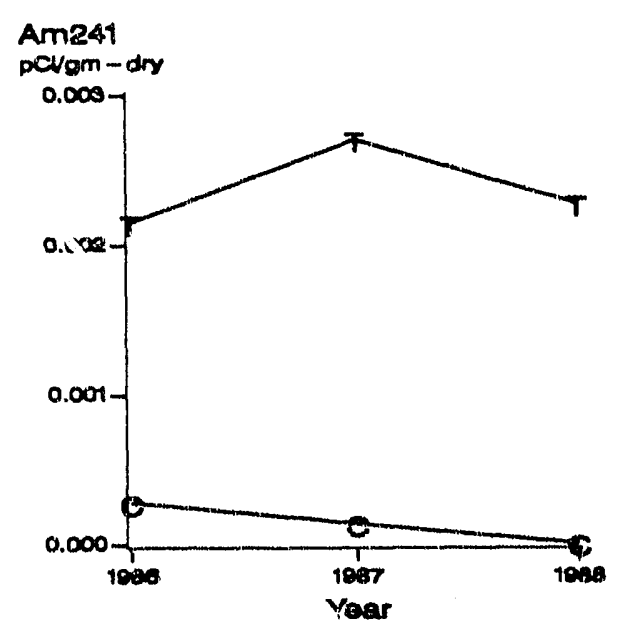

a. ${ }^{241}$ Americium Concentrations

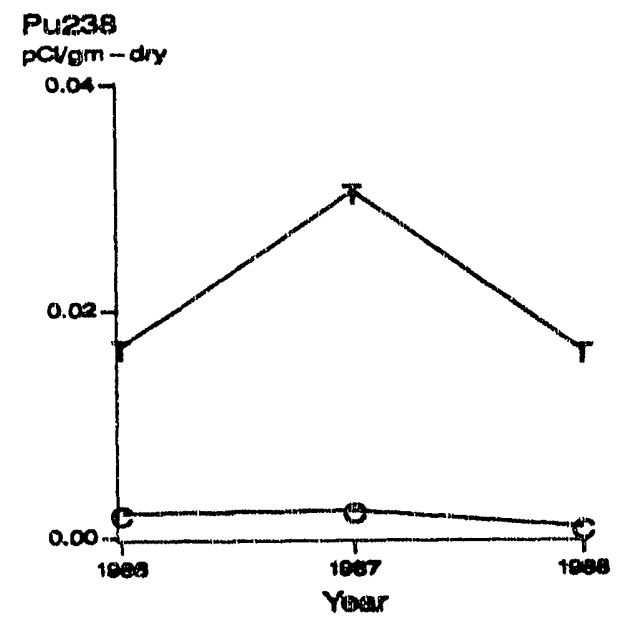

c. ${ }^{238}$ Plutonium Concentrations

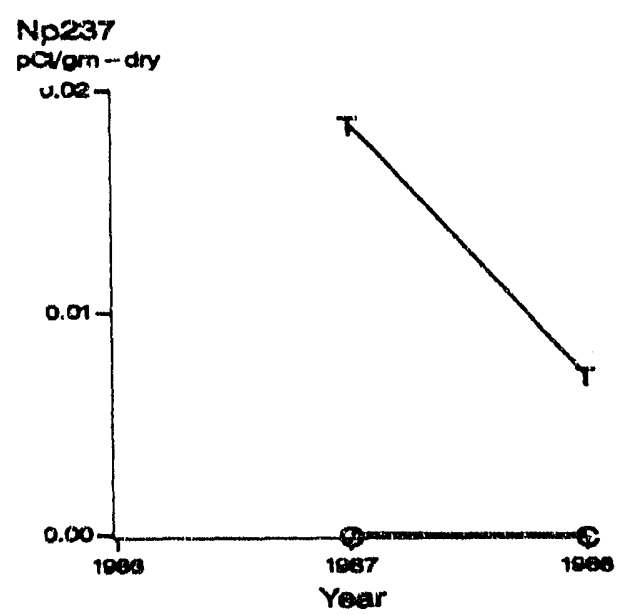

b. ${ }^{237}$ Neptunium Concentrations

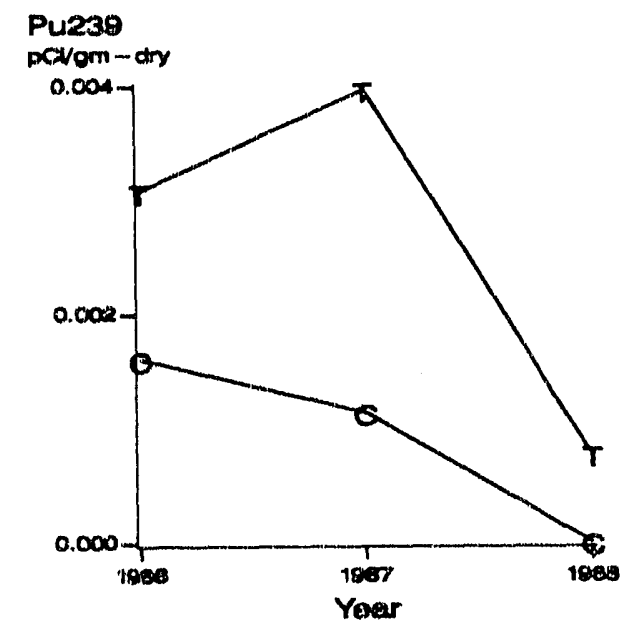

d. ${ }^{239}$ Plutonium Concentrations 
Figure 6. A comparison of the average radionuclide activity of pine needles in control and trench plot trees for each year of sample collection (Contiunued).

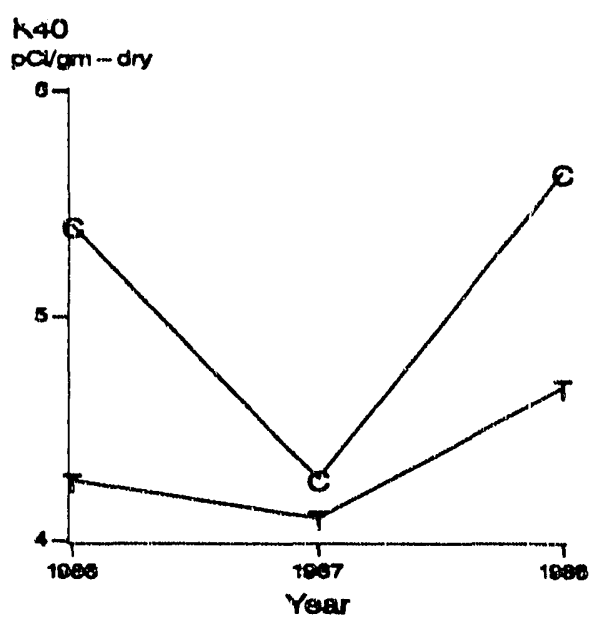

e. ${ }^{40}$ Potassium Concentrations

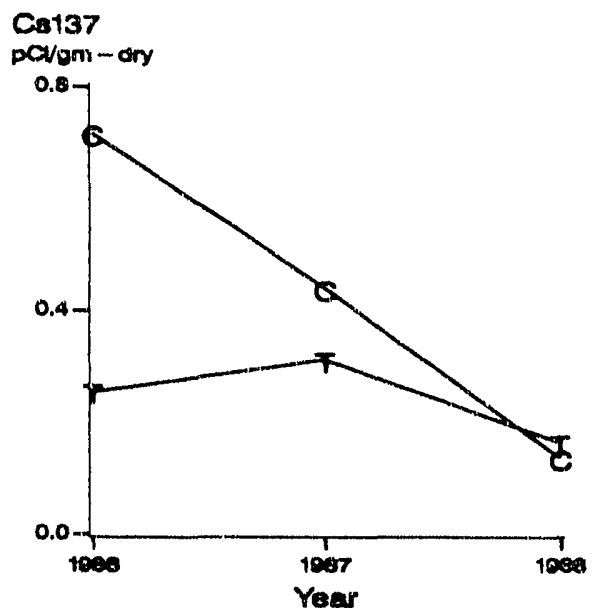

f. ${ }^{137}$ Cesium Concentrations

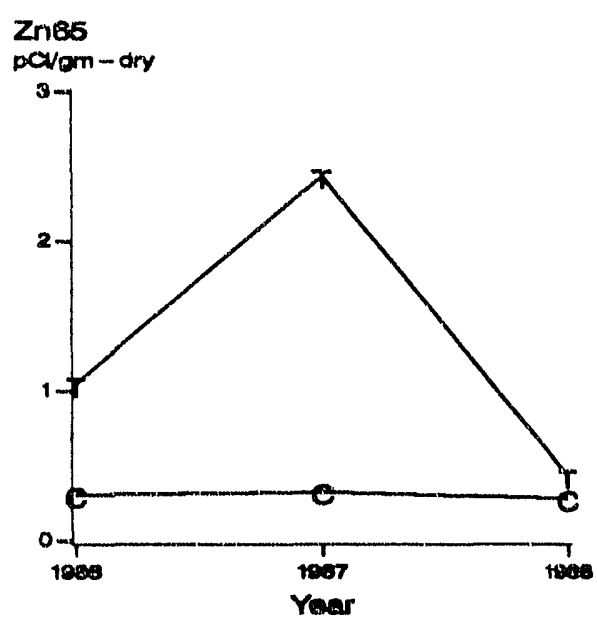

g. ${ }^{65}$ Zinc Concentrations 
ratio of the geometric mean concentrations in the treated and control plots does not differ significantly from one.

Table 5 also shows that there are moderate or strong year effects in three of the seven radionuclides, viz. ${ }^{137} \mathrm{Cs},{ }^{239} \mathrm{Pu}$ and ${ }^{65} \mathrm{Zn}$. It is clear that at least by 1988 there had been a steady and statistically significant decline in radioactive cesium concentrations in pine trees on these study plots. Year-to-year changes in ${ }^{65} \mathrm{Zn}$ geometric mean concentrations, albeit statistically significant, can not be construed as consistently increasing or decreasing.

Concentation of ${ }^{239} \mathrm{Pu}$ demonstrated a strong $(p<.01$ ) interaction effect. This means that the ratio of geometric mean concentrations for the treated and control plots varied significantly from one year to another. This effect is apparent by examination of the interaction plots of geometric mean concentrations for each contaminant in Figures 6a-g.

\section{CONCLUSIONS}

The statistical analysis of the data supports the conclusions that: 1) there are small but significant species differences in ${ }^{238} \mathrm{Pu}$ uptake by tree seedlings (Table 2 and Figure 4);2) there is significantly greater transuranic radionuclide uptake in grown pine trees than in seedlings (Table 3); 3) the greater concentrations of transuranic radionuclides in the trench plo: trees than the control trees are the result of uptake of the radionuclide by the grown pine trees (Table 5 and Figure 6) and 4) there is no apparent time trend in uptake of transuranic nuclides in the grown trees with the possible exception of ${ }^{239,240} \mathrm{Pu}$ (Table 5).

The greater uptake of radionuclides by pine seedlings may be as sult of faster growth and more root penetration into the soil. The greater root penetration into the trench by grown pines is the likely source of the difference in uptaka between seedlings and grown pines. The lack of a time trend in uptake in the older pines may be an indication that their roots have occupied the soil in the trench and are not expanding further. Few studies are available but data summarized by $\mathrm{Koch}^{4}$ suggest that pines can occupy most of the available soil volume

Table 6. Average Transuranic Isotope Activity, Estimated Isotope Transport, and 100 Year Soil Accumulation Activities over Burial Trenches.

\begin{tabular}{|c|c|c|c|c|c|}
\hline & 10 & ${ }^{237} \mathrm{~Np}$ & ${ }^{238} \mathrm{Pu}_{\mathrm{u}}$ & ${ }^{239} \mathrm{Pu}_{\mathrm{u}}$ & ${ }^{241} \mathrm{Am}$ \\
\hline lean concentration & Trench & 0.087908 & 0.026493 & 0.003886 & 0.010940 \\
\hline & Control & 0.000054 & 0.002503 & 0.001059 & $0.00 \times 212$ \\
\hline Transport $^{b}$ & & 34.5 & 10.4 & 1.5 & 4.3 \\
\hline Soil Concentration ${ }^{c}$ & & 11314 & 3410 & 500 & 1408 \\
\hline
\end{tabular}

a) Average of all samples during period (1968-88), $\mathrm{pCi} / \mathrm{gm}$ vegetation.

b) Transport to surface from trench in $\mathrm{pCi} / \mathrm{m}^{2} /$ year, assuming foliage production of $3500 \mathrm{lb} / \mathrm{acre}$.

c) Accumulated soil concentration in the top foot of soil over a 100 year period, $\mathrm{pCi} / \mathrm{m}^{3}$. 
Table7. Concentration Ratios of Transuranic Isotopes for Selected Food Plants, $\mathrm{pCi} / \mathrm{gm}$ of Vegetation $/ \mathrm{pCi} / \mathrm{m}^{3}$ of Soil.

\begin{tabular}{|c|c|c|c|c|}
\hline Eood & ${ }^{237} \mathrm{Nn}$ & ${ }^{238} \mathbf{P u}_{\mathbf{u}}$ & ${ }^{239} \mathbf{P u}_{4}$ & ${ }^{241} \mathrm{Am}$ \\
\hline Barley-Grain & $3.84 \mathrm{E}-06^{\mathrm{a}}$ & $2.44 \mathrm{E}-09^{\mathrm{b}}$ & $1.09 \mathrm{E}-09^{\mathrm{b}}$ & $4.07 \mathrm{E}-09^{\mathrm{b}}$ \\
\hline Barley-Straw & $3.84 \mathrm{E}-05^{\mathrm{a}}$ & $6.86 \mathrm{E}-08^{\mathrm{b}}$ & $5.58 \mathrm{E}-08^{\mathrm{b}}$ & $3.95 \mathrm{E}-07^{\mathrm{b}}$ \\
\hline Pea-Seed & & $2.79 \mathrm{E}-09^{\mathrm{b}}$ & $1.03 \mathrm{E}-09^{\mathrm{b}}$ & $2.09 \mathrm{E}-08^{\mathrm{b}}$ \\
\hline Pea-leaf & & $9.77 \mathrm{E}-07^{\mathrm{b}}$ & $1.74 \mathrm{E}-06^{\mathrm{b}}$ & $1.62 \mathrm{E}-05^{\mathrm{b}}$ \\
\hline Bean-Seed & $1.53 \mathrm{E}-05^{\mathrm{a}}$ & & & \\
\hline Bean-Leaf & $2.07 \mathrm{E}-04^{\mathrm{a}}$ & & & \\
\hline Soybean-Seed ${ }^{c}$ & $3.15 \mathrm{E}-07$ & & $8.76 \mathrm{E}-11$ & 5.71E-09 \\
\hline Soybean-Leaf & $1.22 \mathrm{E}-05$ & & $3.43 \mathrm{E}-08$ & $8.53 E-07$ \\
\hline Pea-Seed ${ }^{\text {c }}$ & $3.80 \overline{\mathbf{D}} 07$ & & $1.18 \mathrm{E}-10$ & $1.77 \mathrm{E}-09$ \\
\hline Pea-Leaf & $2.62 \mathrm{E}-05$ & & 8.07E-08 & $1.60 \mathrm{E}-06$ \\
\hline Wheat-Grain ${ }^{c}$ & $3.43 E-08$ & & $1.16 \mathrm{E}-11$ & $3.20 \mathrm{E}-10$ \\
\hline Wheat-Straw & $1.30 \mathrm{E}-06$ & & 2.40E-09 & $1.69 \mathrm{E}-08$ \\
\hline Tomato-Fruit ${ }^{\mathrm{c}}$ & $4.78 \mathrm{E}-07$ & & $6.48 \mathrm{E}-10$ & $1.33 \mathrm{E}-08$ \\
\hline Tomato-Leaf & $1.00 \mathrm{E}-06$ & & 4.11E-09 & $5.06 E-08$ \\
\hline
\end{tabular}

a) from Cataldo et al., 1987

b) from Schreckhise and Cline, 1980

c) from Romney et al., 1981

in less than ten years.

These measurements indicate that tree roots will extract transuranic isotopes from buried, low-level waste. The amount of radioisotopes moved from the trenches to the surface is small and the level in the trees is low enough that dose from exposure will be small. However, a longer term question is the amount of radionuclides that will move to the surface by trees and incorporated in the surface soil after the foliage drops to the soil surface and decays. This could contaminate the surface soil that would later be planted to food crops.

A rough calculation can be made of the potential for this type of transfer from the SRS alpha trenches. Table 6 summarizes the transuranic isotope transport calculated using the average activity found in the foliage during the $1986-88$ period and a needle production of $3500 \mathrm{lb} / \mathrm{acre}\left(392 \mathrm{gm} / \mathrm{m}^{2}\right)^{4}$. This transport is used to calculate the surface soil activity under the assumptions that all of the radioisotopes accumulated over a 100 year period are held by the soil and the isotopes are evenly distributed in the upper foot of soil by plowing.

Radionuclide specific soil-vegetation concentration factors (Table 7) were used to 
Table 8. Projected Transuranic Isotope Activity in Food Grown in Soil After 100 Years of Vegetation Transport from the Burial Trench to the Soil Surface.

\begin{tabular}{lcccc} 
Eood & \multicolumn{4}{c}{ Crop Concentration, pCi/gm } \\
& ${ }^{237} \mathbf{N p}$ & ${ }^{238} \mathbf{P u}$ & ${ }^{3 \mathbf{P u}}$ & ${ }^{24} \mathbf{A m}$ \\
Barley-Grain & $4.35 \mathrm{E}-02$ & $8.32 \mathrm{E}-06$ & $5.46 \mathrm{E}-07$ & $5.73 \mathrm{E}-06$ \\
Barley-Straw & $4.35 \mathrm{E}-01$ & $2.34 \mathrm{E}-04$ & $2.79 \mathrm{E}-05$ & $5.56 \mathrm{E}-04$ \\
Pea-Seed & & $9.51 \mathrm{E}-06$ & $5.17 \mathrm{E}-07$ & $2.94 \mathrm{E}-05$ \\
Pea-leaf & & $3.33 \mathrm{E}-03$ & $8.72 \mathrm{E}-04$ & $2.29 \mathrm{E}-02$ \\
Bean-Seed & $1.74 \mathrm{E}-01$ & & & \\
Bean-Leaf & $2.35 \mathrm{E}+00$ & & & \\
Soybean-Seed & $3.56 \mathrm{E}-03$ & & $4.38 \mathrm{E}-08$ & $8.04 \mathrm{E}-06$ \\
Soybean-Leaf & $1.38 \mathrm{E}-01$ & & $1.71 \mathrm{E}-05$ & $1.20 \mathrm{E}-03$ \\
Pea-Seed & $4.30 \mathrm{E}-03$ & & $5.92 \mathrm{E}-08$ & $2.50 \mathrm{E}-06$ \\
Pea-Leaf & $2.96 \mathrm{E}-01$ & & $4.04 \mathrm{E}-05$ & $2.26 \mathrm{E}-03$ \\
Wheat-Grain & $3.89 \mathrm{E}-04$ & & $5.84 \mathrm{E}-09$ & $4.51 \mathrm{E}-07$ \\
Wheat-Straw & $1.48 \mathrm{E}-02$ & $1.20 \mathrm{E}-06$ & $2.38 \mathrm{E}-05$ \\
Tomato-Fruit & $5.41 \mathrm{E}-03$ & & $3.24 \mathrm{E}-07$ & $1.88 \mathrm{E}-05$ \\
Tomato-Leaf & $1.14 \mathrm{E}-02$ & & $2.05 \mathrm{E}-06$ & $7.12 \mathrm{E}-05$
\end{tabular}

calculate the radionuclide activity in vegetable crops from the soil radionuclide concentrations (Table 6). In all cases, the activity of the transuranic isotopes in the edible portion of the plants is quite low (Table 8), , $^{9,11}$. The activity in the leaf tissue is much higher than in the seed and may be of some concern. However, it should be noted that in no case is the activity higher than the natural occurring activity of ${ }^{40} \mathrm{~K}$ in the pine foliage.

The data synthesized by Watters et al. ${ }^{1}$ suggests that the availability of transuranic isotopes for plant uptake is related to their mobility in the soil. If this is true, isotopes which are not readily available, such as ${ }^{238} \mathrm{Pu}$ and ${ }^{239} \mathrm{Pu}$, will accumulate in the surface soil over long periods of time and the activity in the surface soil can be expected to increase linearly with time. In this case, the activity of the soil and the plants grown in the soil will be four times higher at 400 years than it was at 100 years. More available isotopes, such as ${ }^{237} \mathrm{~Np}$ and ${ }^{241} \mathrm{Am}$ should also be more mobile in the soil system. In this case, the addition by vegetative uptake may be balanced by leaching at some time in the future and a steady state soil activity established.

The major findings from the statistical analysis of these data are: 1) there is evidence for significant increases in ${ }^{237} \mathrm{~Np}$, ${ }^{241} \mathrm{Am}$, ${ }^{238} \mathrm{Pu}$, and ${ }^{239} \mathrm{Pu}$ concentrations in the treated plots when compared to control plots and 2) that there is insufficient evidence for a consistent pattern of radionuclide uptake from one year to another. 


\section{SUMMARY}

From the results of this study, it is evident that small amounts of transuranic radionuclides can be transported from a burial trench to the surface soil by the action of trees growing over the trench. The uptake by trees growing above the trench is very variable, reflecting the heterogeneity of the activity within the trench and the chance of root contact with contamination.

The calculated amount of radionuclides accumulated over longer periods is small in comparison with natural radioactivity in the same soil. However, it would be prudent to continue this experiment to determine whether there is a time trend in uptake by the vegetation.

Two elements of the experimental design need to be recognized if the study is to continue. There has been a large amount of mortality to the trees in the control plot because of herbicide treatment of an adjacent area. In a few years, there will not be enough control trees to allow statistical analysis. A solution would be to establish another control plot in trees of approximately the same age and measure these trees with the hope of establishing that they are not significantly different from the control trees that are left. It is almost certain that these trees can only be located outside of the burial ground. This should not prove to be a major problem since there is unlikely to be significance to the location of the control plot.

The other element is the choice of the contractor to make the measurements of transuranic activity in the trees. The results of the two contractors used are both satifactory in terms of sensitivity. The statistical tests showed no difference from year to year, implying that the two analyses did not differ. However, inspection of the data does suggest, but not prove, that there is some difference between laboratories. The difference does not affect the ability to tell the difference between control and trench plots since both analysis show this difference clearly. However, it may affect the ability to determine time trends. For this reason, it would be better to stay with one laboratory for the remainder of this study. A desirable adjunct to this study would be a study of the consistency and reprod :cability of transuranic nuclide concentration analysis in vegetation samples among the candidate laboratories. This could be accomplished by submitting duplicate samples to each laboratory.

\section{REFERENCES}

1 R.L. Watters, D.N. Edgington, T.E. Hakonson, W.C. Hanson, M.H. Smith, F.W. Whicker, and R.E. Wildung. "Synthesis ofresearch literature". Transuranic Elements in the Environment. ed.W.C. Hanson. DOE/TIC-22800, NTIS, Springfield, VA, pp. 1-44. (1980).

2 J.H. Horton and J.C. Corey. Storing Solid Radioactive Wastes at the Savannah River Plant. DP-1366 E.I. du Pont de Nemours and Company, Inc., Savannah River Laboratory, Aiken, SC 29808 (1976).

3 D.R. Johnson and E.L. Wilhite. Migration of transuranic nuclides in earthen burial trenches at the Savannah River Plant. USDOE Report, DP-MS-79-20 E.I. du Pont de Nemours and Company, Inc., Savannah River Laboratory, Aiken, SC 29808 (1979). 
4 P. Koch. Utilization of the Southern Pines. Volume I. USDA, Forest Service, Superintendent of Documents, U.S. Government Printing Office, Washington, D.C. 734 p. (1972).

5 P.J. Kamer and T.T. Kozlowski. Physiology of Trees. p. 229, McGraw Hill Book Company, New York (1960).

6 R.D.G. Steele and J.H. Torrie. Principles and Procedures of Statistics. McGraw-Hill Book Company, Inc. New York, 481 p. (1960).

7 B. J. Winer. Statistical Principles in Experimental Design. Second Edition. New York, NY. McGraw Hill (1971).

8 SAS. SAS/STAT User's Guide, Release 6.03 Edition. SAS Institute, Inc., Cary, NC, 1028 p. (1988).

9 R.G. Schreckhise and J.F. Cline. "Comparative uptake and distribution of plutonium, americium, curium, and neptunium in four plant species". Transuranic Elements in the Environment. ed. W.C. Hanson. DOE/TIC-22800, NTIS, Springfield, VA, pp. 361-370 (1980).

10 D.A. Cataldo, T.R. Garland, and R.E. Wildung. " Neptunium behavior in plants: absorption, distribution, and fate". Environmental Research on Actinide Elements. eds. J.E. Pinder III, J.J. Alberts, K.W. McLeod, and R.G. Schreckhise, DE86008713,NTIS, Springfield, VA, pp. 97-108 (1987).

11 E.M. Rornney, A. Wallace, R.K. Schulz, Jean Kinnear, and R.A. Wood. "Plant Uptake of ${ }^{237} \mathrm{~Np},{ }^{239,240} \mathrm{Pu},{ }^{241} \mathrm{Am}$, and ${ }^{244} \mathrm{Cm}$ from Soils Representing Major Food Production Areas of the United States". Soil Science 132,, p40 (1981). 


\section{ACKNOWLEDGEMENTS}

The information contained in this report was developed during the course of work under Contract DE-AC09-88SR18035 with the U.S. Department of Energy. The assistance of T.R. Johnson, E.L. Wilhite and D.R. Johnson who completed the early stages of this work is gratefully acknowledged. 
APPENDIX

Concentration of Radionuclides Measured for All Plots and Years

-19- 
Needle Activity from Pine Trees During 1986-88 (pCi/gm).

\begin{tabular}{|c|c|c|c|c|c|c|c|c|c|}
\hline Per & & Tre & ${ }^{247} \mathrm{ND}$ & ${ }^{241} \mathrm{Am}$ & ${ }^{238} \mathrm{Pu}_{\mathrm{u}}$ & ${ }^{239} \mathrm{Pu}$ & ${ }^{137} \mathrm{Cs}$ & ${ }^{40} \mathbf{K}$ & ${ }^{65} \mathrm{Zn}_{\mathrm{n}}$ \\
\hline & $\mathrm{T}$ & $10 \mathrm{~A}$ & 0 & 0.010400 & & & & & \\
\hline & $\mathrm{T}$ & & 0.01 & 0.000584 & 0.02510 & 0.002700 & 0 & 470 & 2.0640 \\
\hline , & $\mathrm{T}$ & $10 B$ & 0.000 & 0.000436 & 0.08370 & 0.002010 & & 2.822 & 4.0450 \\
\hline 1987 & $\mathrm{~T}$ & 7 & 48400 & .026200 & 0.02990 & 0.007100 & & .601 & 2.6380 \\
\hline 87 & $\mathrm{~T}$ & 0 & .00704 & .002070 & 0.03170 & 10 & & & 390 \\
\hline 1987 & $\mathrm{C}$ & 14 & 5 & & & & & & \\
\hline 7 & $\mathrm{C}$ & $5 A$ & 00031 & 010 & 0.0 & & & & 0.3098 \\
\hline 87 & $\mathrm{C}$ & $5 B$ & 01 & 37 & 40 & & & 56 & 0.2 \\
\hline 10 & $\mathrm{C}$ & 6 & 0.0 & 1 & & & & & \\
\hline 86 & $\mathrm{~T}$ & $10 \mathrm{~A}$ & & $0.0^{\circ}$ & 0.0 & 0 & & 28 & 0.9563 \\
\hline & $T$ & 6 & & & & & & 92 & $\$ 15$ \\
\hline 86 & $\mathrm{~T}$ & $10 B$ & & 52 & & & & & 940 \\
\hline & $\mathrm{T}$ & 7 & . & 90 & & & & & 0.8702 \\
\hline & $\mathrm{T}$ & 8 & . & 5 & & & & & 1.0720 \\
\hline 86 & $\mathrm{C}$ & 14 & & 43 & 0.0 & & & & 0.1685 \\
\hline & $\mathrm{C}$ & 3 & & 39 & 0.0 & & & 32 & 0.1700 \\
\hline 198 & $\mathrm{C}$ & $5 \mathrm{~A}$ & & 70 & & & & 49 & 0.2204 \\
\hline 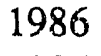 & $\mathrm{C}$ & $5 B$ & & 682 & 0.0 & & & & 0.9268 \\
\hline 10 & C & 6 & & 154 & 0.0 & & & 6.609 & 0.4932 \\
\hline 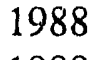 & $\mathrm{T}$ & 6 & & 00 & 25 & & & 3.750 & 0.7500 \\
\hline 198 & $\mathrm{~T}$ & 8 & 0.00925 & 0.06 & 0.0 & & & 7.250 & 0.4500 \\
\hline מר & $\mathrm{T}$ & 10 & & 0.0 & & & & 7.000 & 0.6500 \\
\hline & $\mathrm{T}$ & 7 & 0.19175 & 0.0 & 0.0 & & & 4.750 & 0.3750 \\
\hline 198 & $\mathrm{~T}$ & $10 \mathrm{~B}$ & 0.00001 & 0.000010 & 0.0 & & 0.5 & 2.500 & 0.0000 \\
\hline 198 & $\mathrm{C}$ & $5 \mathrm{~A}$ & 0.00001 & 10 & 0.0 & & & 8.500 & 0.0000 \\
\hline 198 & $\mathrm{C}$ & 8 & 0.00001 & 0.000010 & 0.00275 & 0.00 & 0.14750 & 5.500 & 0.0000 \\
\hline & $\mathrm{C}$ & 14 & & 0.000010 & 0.00400 & 0.000 & 0.00000 & 8.500 & 0.0000 \\
\hline & $\mathrm{C}$ & 6 & & & & & & 2.500 & 1.4750 \\
\hline 198 & $\mathrm{C}$ & $5 \mathrm{~B}$ & 0.00001 & 0.000010 & 0.00200 & 0.00 & 0.45000 & 5.750 & 0.000 \\
\hline
\end{tabular}


Tree Leaf Activity from Seedlings Sampled in 1979,1980, (pCi/gm).

\begin{tabular}{|c|c|c|c|c|}
\hline Year & Plat & Species & ${ }^{238} \mathrm{Pu}_{\mathbf{u}}$ & ${ }^{239} \mathrm{Bu}$ \\
\hline 1979 & $\mathrm{~T}$ & pine & .0012533 & .0003867 \\
\hline 1979 & $\mathrm{~T}$ & pine & .0006333 & .0005133 \\
\hline 1979 & $\mathrm{~T}$ & oak & .0013300 & .0008667 \\
\hline 1979 & $\mathrm{~T}$ & oak. & .0018667 & .0004667 \\
\hline 1979 & $\mathrm{~T}$ & sweetgum & .0003800 & .0001187 \\
\hline 1979 & $\mathrm{~T}$ & sweetgum & .0002670 & .0004633 \\
\hline 1979 & $\mathrm{C}$ & pine & .0008800 & .0051000 \\
\hline 1979 & C. & pine & .0005867 & .0001717 \\
\hline 1979 & $\mathrm{C}$ & oak & .0020633 & .0013300 \\
\hline 1979 & $\mathrm{C}$ & oak & .0011500 & .0011467 \\
\hline 1979 & $\mathrm{C}$ & sweetgum & .0030733 & .002 .5700 \\
\hline 1979 & C & sweetgum & .0001337 & .0001267 \\
\hline 1980 & $C$ & pine & .0034333 & .0018667 \\
\hline 1980 & $C$ & pine & .0012000 & .0013667 \\
\hline 1980 & $C$ & oak & .0005667 & .0004667 \\
\hline 1980 & C & oak & .0026333 & .0010657 \\
\hline 1980 & C & oak & .0006333 & .0008667 \\
\hline 1980 & $\mathrm{C}$ & oak & .0007667 & .0002667 \\
\hline 1980 & C & pine & .0007000 & .0008000 \\
\hline 1980 & $\mathrm{C}$ & sweetgum & .0001000 & .0002333 \\
\hline 1980 & $C$ & sweetgum & .0007667 & .0008333 \\
\hline 1980 & $\mathrm{C}$ & sweetgum & .0001667 & .0002667 \\
\hline 1980 & $T$ & oak & .0010333 & .0013667 \\
\hline 1980 & $T$ & oak & .0012000 & .0010333 \\
\hline 1980 & $\mathrm{~T}$ & pine & .0056667 & .0000100 \\
\hline 1980 & $T$ & pine & .0032000 & .0022333 \\
\hline 1980 & $\mathrm{~T}$ & sweetgum & .0002000 & .0008000 \\
\hline 1980 & $\mathrm{~T}$ & sweetgum & .0007000 & .0010333 \\
\hline 1980 & $\mathrm{~T}$ & oak & .00066667 & .0005667 \\
\hline 1980 & $T$ & oak & .0005000 & .0008333 \\
\hline 1980 & $\mathrm{~T}$ & oak & .0007667 & .0005333 \\
\hline 1980 & $\mathrm{r}$ & sweetgum & .0004667 & .0005667 \\
\hline 1980 & $\mathrm{~T}$ & sweetgum & .0002000 & .0005667 \\
\hline 1980 & $\mathrm{~T}$ & sweetgum & .0005000 & .0013000 \\
\hline 1980 & $\mathrm{~T}$ & pine & .0009000 & .0038667 \\
\hline 1980 & $\mathrm{~T}$ & pine & .0012000 & .0018333 \\
\hline
\end{tabular}



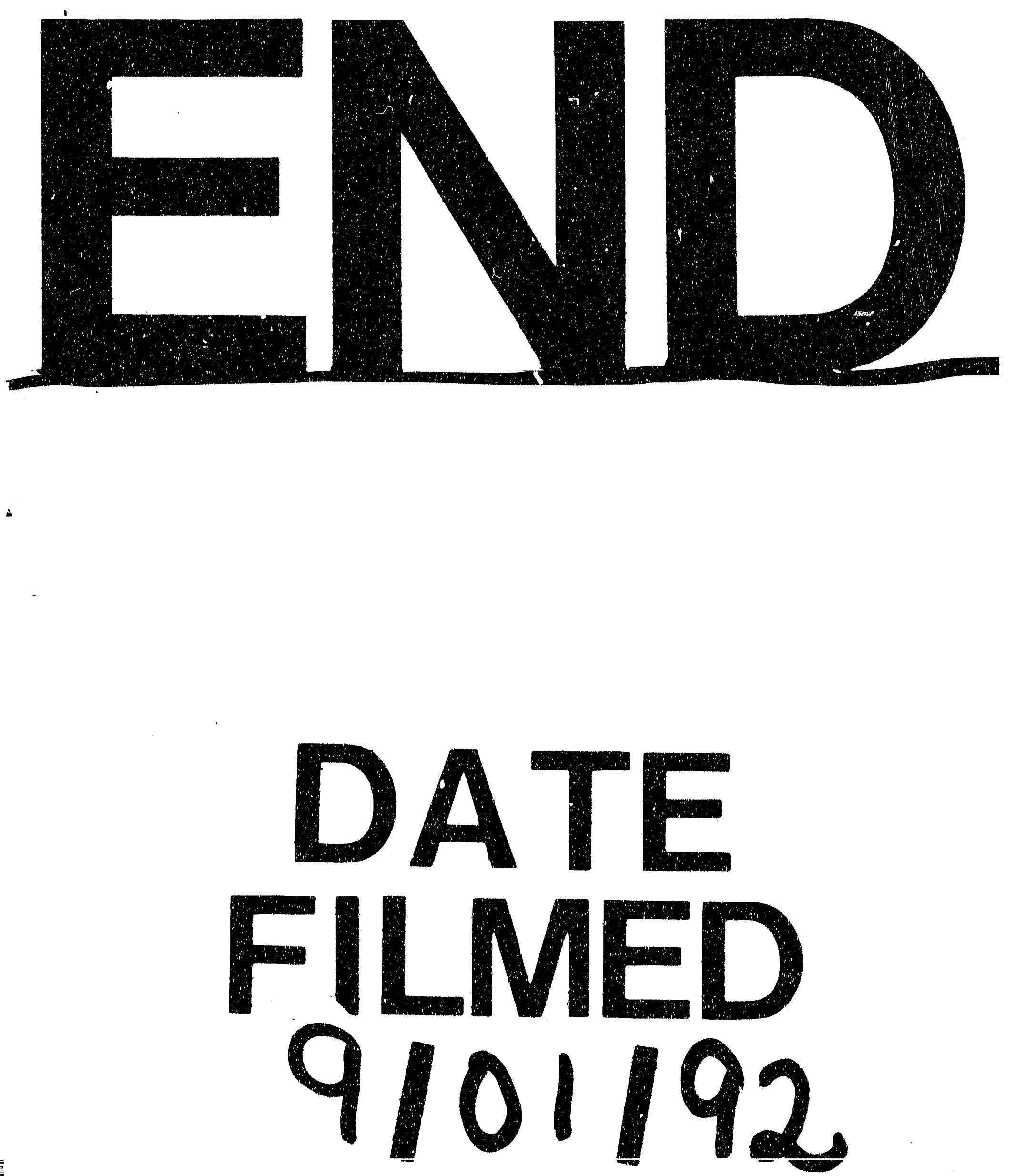
